\title{
Predictors and outcome of customer satisfaction: moderating effect of social trust and corporate social responsibility
}

Sara Javed ${ }^{1}$, Md. Salamun Rashidin ${ }^{1,2^{*}}$ and Wang Jian $^{2}$

\begin{abstract}
The study is to present an integrative model of predictors and outcome of customer satisfaction in the fast food sector of Pakistan and also examine its effects. Moreover, we also examined the contingent effect of social trust and corporate social responsibility (CSR) on the relationship between customer satisfaction and brand loyalty. Offline and online survey was conducted with four hundred fast food customers; valid data were assessed and analyzed through structural equation modeling and moderation step-by-step approach. Results demonstrate that restaurant stimuli such as food quality, service quality, atmosphere, price, restaurant location and a variety of food have strong significant effects on customer satisfaction, and customer satisfaction engendered brand loyalty. Social trust has a positive significant impact on the relationship between customer satisfaction and brand loyalty, whereas on the other side CSR has insignificant impact on the association. The study has practical implications for both restaurateurs and government. Restaurateurs should ensure the safety standards of foods, and the government can take an initiative to set proper policy and maintain the food safety standards by regulation.
\end{abstract}

Keywords: Customer satisfaction, Brand loyalty, Social trust, Service quality, Fast food industry, Corporate social responsibility

\section{Introduction}

In the present era, hospitality industry is observing diversified changes in highly competitive environment for restaurant [1]. Fast food industry of Pakistan is undergoing an escalated boom. There is a growing trend in Pakistani culture to dine out at fast food restaurants with family, friends and colleagues [2]. Consumers switch easily in case of just one evasive experience. Fast food restaurants must attract new customers and retain the existing customers. Restaurants focus to provide a dining experience by combining tangible and intangible essentials [3]. The objective is to achieve customer satisfaction (CS), brand loyalty (BL) and repeat purchase patronage at fast food

\footnotetext{
*Correspondence: salamun.du@outlook.com

${ }^{2}$ School of International Trade and Economics, University of International, Business and Economics (UIBE), No.10, Huixin Dongjie, Chaoyang District, Beijing 100029, China

Full list of author information is available at the end of the article
}

restaurant. A number of studies on the consumption in restaurants have been carried out; in some of these studies, researchers have been more focused on customer dining behavior because food is a vital element to comprehend one's society or culture, while other researchers have been interested in identifying the important service dimensions of restaurant which are, menu, cleanliness, style, price, ambience, location [4] food quality [5], chef, service staff and atmosphere, These service dimensions determine the dining behavior and revisit intention of the clientele.

Moreover, studies on restaurant found that menu, location and atmosphere affect customer satisfaction and the ultimate brand loyalty. Furthermore, brand loyalty is the outcome of customer satisfaction [6,7]. It enables the restaurant patron to decline to move/switch to another restaurant, no matter how effective the marketing is and whatever the situation is Rahi [8]. Cultivating brand loyalty is important as far as the service sector is concerned, 
especially where service providers render services with minor distinctions and fight in turbulent environment particularly in the fast food industry as suggested by Santouridis and Trivellas [9]. In Pakistan, CSR is cost or investment it has not yet been clearly defined [10]. Therefore, it would be right to say that customers can switch to other products and services despite corporate social responsibility practices being executed by those organizations with whom they are connected for some period of time as they have a choice to switch purchase decisions [10]. Especially in Pakistan, in the hotel and restaurant industry it has been observed that the customer switching is high which shows a clear gap that need to be filled that how customer switching can be controlled in hotel and restaurant industry [10]. Additionally, customers are now conscious to dine out from the restaurant that are socially responsible, meet all ethical and legal standards or engaged in social causes [11]. Various types of CSR messages can influence customers' attitudes differently, the way that a company frames and presents its CSR message is important [12]. In our study, restaurant menus can serve as a tool to communicate a restaurant's CSR actions to customers. Healthy food items on restaurant menus show customers that restaurants care about their well-being, creating positive CSR perception for customers [13]. Furthermore, societies nonprofit, charities activities, etc., have positive influences on loyalty. Restaurants are favorably evaluated by customers if it is positively linked up by any CSR activities. Demonstrating a socially responsible behavior toward society increases the customer satisfaction and loyalty and ultimately influences the brand loyalty [14]. Numerous studies have examined the relation of brand trust with brand loyalty [15] even though the role of social trust on customer routine dealings and its ultimate effect on brand loyalty have not yet been explored. This is due to the fact that the customer's collective thought about people is greatly influenced by his personality traits (like tolerance, faith on people, cooperative, optimistic, pessimist etc. and whatever is going on in a society [16]. Customer responses toward any situation clearly depict how much contented they are with their society as well as with their personal lives. A customer's lack of trust in the society greatly affects his links with restaurants as it is operating in a society, where he generally starts distrusting others and reduces his trustworthiness behavior [17]. Moreover, strong relational ties and higher satisfaction with society lead to trustworthiness [13]. According to Boix and Daniel [18], who further describe the notion of Putnam [19], a clientele who has low trust may be dissatisfied with a restaurant when the restaurant doesn't meet some standard of honesty more than once and eventually results in the customer taking a decision of continuing or discontinuing. The individual personality traits play a crucial role in this decision, though this 'moral yardstick' decreases social trust. Moreover, adding to the previous example, clientele believes that people cannot be trusted or infers all people come in the same category, especially in societies where customers hold low social trust. In this manner, customer revisit intention is negatively affected [20] and vice versa.

Brand loyalty is a big challenge in the restaurant industry, and it has declined over the years [21]. It calls upon the researcher's attention to pinpoint the crucial factors in the eye of restaurant patrons, because switching cost of restaurants customers is very low. A number of extant studies investigate the predictors of brand loyalty and of customer satisfaction [22,23]. The study fills the aforementioned gap by presenting an integrative model of predictors and outcome based on customer satisfaction. Moreover, we also examined the contingent effect of social trust on the relationship between customer satisfaction and brand loyalty, though how individual social trust influences his routine matters/dealings has been overlooked.

The basic premise of this study is to fill the slot in the existing body of literature by giving an integrated model to examine the effect of customer satisfaction on brand loyalty due to certain drivers, more specifically, (1) examining the factors that bring back the customer in fast food restaurants for another meal, (2) investigating the effect of factors on customer satisfaction, (3) examining the direct effect of customer satisfaction on brand loyalty, (4) the indirect effect of factors on brand loyalty through customer satisfaction, (5) moderating effect of social trust on the relationship between customer satisfaction and brand loyalty and (6) moderating effect of corporate social responsibility (CSR) on the relationship between customer satisfaction and brand loyalty. The study theoretically contributes to the literature on customer satisfaction by providing an integrative model on customer satisfaction with predictors and outcome. The present study also makes a contribution to the studies on restaurant perspective by integrating the model of predictors and outcomes of customer satisfaction. The study validates the interactive effect of moderating variable social trust with customer satisfaction which helps strengthen the association between customer satisfaction and brand loyalty, and this effect has never been investigated earlier.

Furthermore, the study extends current literature by demonstrating that customer satisfaction fully mediates between predictors (food quality, service quality, restaurant atmosphere, restaurant location, price and menu) and outcome variable (brand loyalty). For practitioners, the findings of the study give suggestions to fast food restaurateurs to devise some effective strategies to keep 
them satisfied by incessantly evaluating their feedback, ask for suggestions, keep an eye on complaint boxes, being aware of their complaints etc. For the government, this study gives insight that customer brand loyalty and customer satisfaction are influenced, to some extent, by societal trust therefore governments need to devise some strategies to increase the individual general trust of the society.

The remaining part of the study is presented as follows: "Research model and hypotheses development" section discusses the theoretical framework and model development, "Corporate social responsibility" section presents the adopted methodology, analysis and major findings, and "Discussion" section makes the final discussion on results as well as draws the conclusion followed by outlining the practical and theoretical implications, limitations and future directions for forthcoming researchers.

\section{Research model and hypotheses development Food quality}

Food quality is one of the central features of a restaurant's dining experience [24]. It is among the attributes that affect consumer behavioral intentions regarding restaurant dining [25]. Since food quality is considered as a key element in defining the success of the restaurant business, a research done by Qin and Prybutok [26] investigates the restaurant attributes impact on old diner's intention to re-patronize the restaurant. The findings suggest that food quality was the key item to revisit the restaurant. The result of this study is in line with the studies of Haghighi et al. [27], who found out that food quality has a positive impact on customer satisfaction. Mattila [28] expressed the peak three reasons of customers to visit their marked restaurant which were food quality, service and atmosphere. As Andaleeb and Conway [29] found, a top cause behind re-patronage to restaurants was food quality. According to Ryu and Han [30], the quality of food was the most vital characteristic among all restaurant dimensions which offered to customers and has a positive association with customer satisfaction and brand loyalty.

In a restaurant setting, food quality is measured through its freshness, temperature and getting the errorfree food at the first time [31]. Surprisingly, another study provides support conducted by Namkung and Jang [32] and Schiffman and Kanuk [33] on presentation/aesthetic appeal, nutritional value, aroma, taste, cleanliness and freshness on the key factors that make up food quality and which are considered as the most important reason for visiting the quick service restaurants. As customers visit a restaurant to satisfy their hunger, food quality is paramount in attracting and retaining to them in the dining place [34].
Therefore, we can hypothesize that:

H1 Food quality has a positive influence on customer satisfaction in fast food industry of Pakistan.

\section{Service quality}

The term service can be defined in a variety of ways depending on the field in which it is used. Kotler and Keller [35] defined the concept service as "any intangible act or performance that one party offers to another that does not result in the ownership of anything". It is also defined as total features and the attributes of the product and services that satisfy the real or implied needs of the customers [36]. Service quality is defined as a customer's perception about the services that may meet or exceed his expectations [37]. It is considered as a momentous feature of restaurant dining. Service quality is equally important as of food quality and plays a vital role in building up the perception to re-patronage. In restaurant setting, studies emphasized that service quality is an imperative determinant of customer satisfaction and re-patronage [38]. In turbulent market environments, service quality is identified as a crucial element for the success of fast food restaurants as it has a great impact on consumer behavior as it either induces satisfaction or dissatisfaction; hence, improvement in service quality helps fast food operators to compete, retain the existing customers and attract new customers [39]. Past studies emphasized the role of service quality in the determination of customer satisfaction which customer encounters at the restaurant setting (dimensions: friendliness staff, courteous, quick service line, waiting time, etc. [40] as well as the consumer's behavioral intention to revisit [41]. Thus, we can extrapolate from previous findings that improved service quality results in a satisfied or contented customer [42] which leads to brand loyalty. Therefore, we can hypothesize that:

H2 There is a positive association between service quality and customer satisfaction in fast food industry of Pakistan.

\section{Atmosphere}

In restaurants industry, atmosphere is perceived as a crucial element [43]. This is because it influences a customer's emotions and expectations as well as dining experience [44]. According to Bitner [45] and Zeithaml et al. [46], customers initially look upon the atmosphere to take any services; the buildup perception about the service scape may affect the customer's reaction to the services delivered in restaurants [46, 47]. The perceived 
atmosphere draws cognitive responses, which further influences the patron beliefs about a place, services, staff and products. Moreover, if a customer has a high perception about the restaurant atmosphere, then customers' expectations for service could also be high. The perception about the restaurant services cape directly influences customer satisfaction. According to Auty [48], in restaurant setting after food quality, variety of food and price, atmosphere is considered as a major element that differentiates one service provider from another. Thus, we can say that the atmosphere has become essential in restaurant settings because customers tend to be provoked by atmospheric stimuli such as lights, ambiance, style, cleanliness, comfortable seats or aesthetic elements, music and noise which subsequently increases the behavioral intention or repeat patronage [49]. Furthermore, Chang [50] recommended that perception about physical surroundings is a direct marker of a customer's satisfaction; in this manner, customer satisfaction is directly linked with the facet of constructive behaviors. Thus, we can hypothesize that:

H3 Restaurant atmosphere has significant influence on customer satisfaction in fast food industry of Pakistan.

\section{Restaurant location/convenience}

Gone are the days when food quality was a prime focus of restaurateurs; nowadays customer put their attention to other factors too like atmosphere, variety of food and location [51]. Klassen et al. [52] carried out a study about the scheduling of food services in a campus setting. The results of the study indicated that because students have less time to go out of the university, they prefer to purchase from the university cafe in order to satisfy their hunger need because they like short walking distance for a quick meal. Another study by Mattila's [28] found out that customers prefer to visit the restaurant which is located at a convenient place. Moreover, in the study executed by Kivela et al. [53] based on restaurants themes the author put the parking area under the category of convenience. The result indicated that a parking area really matters for the customers of the restaurant. While Lewis and Shoemaker [54] found in his study that short walking distance got importance among the clientele of restaurants, and a convenient location is related with customer satisfaction, purchasing intention and ultimately brand loyalty $[55,56]$. If restaurateurs would like to get clientele satisfaction, they should make sure that there is easy accessibility as well as a convenient location. According to Hassan et al. [57], urban life-style imposes time constraints, so customer seeks convenience and wants to satisfy their hunger with minimum hassle. Customers of restaurants always suppose a fine location of restaurant where they can easily park their car. Car parking facility has a substantial impact on creating brand loyalty, consequently. Restaurants try to provide free parking for customers that facilitate them [57]. Therefore, we can propose that:

H4 There is a positive influence of restaurant location on customer satisfaction in fast food industry of Pakistan.

\section{Price}

Price has been perceived as an important factor in elucidating the behavior of customers. It can be defined as what the customer paid or sacrificed to get the product or services [58]. It is an influential and persuasive tool to attract customers to buy from a particular brand. Similarly, Pride and Ferrell [59] considered price as a tool which tells the customers about the worth of the product. Customers usually estimate the value of the product or services offered via price [60]. In the restaurant industry, the price of the items on the menu varies from restaurant to restaurant. Due to intense competition in the restaurant industry, customers may develop internal reference prices [61]. Few studies examined the association between price and customer satisfaction and behavioral intentions of re-patronage. Oliver and Swan [62] considered the price as an antecedent of customer satisfaction. They also stated that the customer makes a comparison of his or her existing payment with expectation, assessing whether the actual compensation is high or low than what he thinks is required. The more he found balance in price/value trade-off, the more he tends to be satisfied with the services of the restaurant. Klassen et al. [52] conducted a study in which he found that $62 \%$ of the students believed that price is the most imperative reason for making a decision to dine out from a particular restaurant. In addition to this, Bolton and Lemon [63] found a direct link of price with customer satisfaction. Once customers are certain that they are getting paramount quality of product or service, they tend to be loyal in the long run. Moreover, Ali Shafiq et al. [64] suggested that the perceived price had a positive impact on customer satisfaction. If the product or service gives more value in terms of attributes, then such type of customers is ready to pay a premium price in the restaurant sector [61]. Many investigators found perceived price as an imperative determinant of customer repeat buying behaviors. Therefore, we hypothesize that,

H5 Price has positive influence on customer satisfaction in fast food industry of Pakistan. 


\section{Variety of food}

Variety of food is also recognized as variety in menu [65]. Majority of the studies indicated that variance in food greatly influences a patron's perception about the restaurant setting [66] and developed a perception which influences the customer satisfaction and repeat-restaurant patronage [67]. The accessibility of a variety of products/ services is of importance in the restaurant industry and increases the likelihood of repeat patronage of variety seekers. It is in line with Barbara [68] study in which he viewed the importance of variety-seeking in the service sector. It is defined as "the tendency of individuals to seek variety in their choices". According to Ratner et al. [69], it is in human nature that he looks toward change because he gets bored by using similar stuff. That's why, restaurant customers seek out different types of food, try new food and taste. Zandstra et al. [70] conducted a study on the consumption of meat sauce at dinner time in home that last longer 10 weeks at dinner time. The results indicated that as the days passed, it became the cause of boredom among the family members and lowered down their consumption. Another study conducted by Bjorvatn and Wald [71] revealed that sandwiches with different fillings would bring some variety in taste, whereas, on the other side, the study on consumption of eight sandwiches with different fillings indicated that it would bring the customers maximum diversity in taste. Therefore, we hypothesize that,

H6 Variety of food has positive influence on customer satisfaction in fast food industry of Pakistan.

\section{Brand loyalty}

The notion of brand loyalty has changed over the decades [72, 73]. Earlier, it was considered a univariate measure in terms of repeat buying behavior [74, 75]. Subsequently, it was felt as a complex multi-dimensional construct. Brand loyalty is defined as "a deeply held commitment to re-buy or re-patronize a preferred product/service consistently in the future, thereby causing repetitive same-brand or same brand-set purchasing, despite situational influences and marketing efforts having the potential to cause switching behavior" [76]. Moreover, the present study measured the brand loyalty by the suggested three dimensions of brand loyalty which are affective/emotive loyalty, cognitive/ attitudinal or evaluative loyalty and behavioral loyalty. The first approach to brand loyalty is affective loyalty as admiration or conformity propensity which is thoroughly manifested in favor of a brand than rival brands in the market. The second approach of brand loyalty is cognitive/evaluative loyalty with brand. It refers to as the positive evaluation of a specific brand by the customer on set criteria. The third approach to brand loyalty is behavioral loyalty toward the specific brand. It refers to the upbeat reaction toward buying and consumption activities [77]. From behavioral perspective in the case of restaurant setting, loyalty demonstrates the number of visits [78].

The concept of brand loyalty is relatively more important for services sector, especially for those who provide services with minor distinctions and contend in dynamic environment particularly in fast food industry [9]. The matter of the fact is that loyal customers are more likely to spend chunks of money on the restaurant products or services and are less sensitive to price. This cohesive bonding between customer and restaurant placed a positive impact on its profitability [79]. That's why restaurants use defensive marketing strategies to grab more market share and profits by establishing the brand loyalty [80].

\section{Customer satisfaction and brand loyalty}

Satisfaction is defined as customer evaluative judgments about specific products/services and purchasing [81, 82]. Customer satisfaction is defined as an overall assessment of product or service with experiences. According to Khadka and Maharjan [83], products quality, service, price, environment and place influence the customer satisfaction. A satisfied customer tends to repurchase products and become loyal customers, and they are positively engaged in giving recommendations to other customers and less sensitive to price. However, once customers are satisfied with a product or brand, they are more likely to recommend the brand to others or are more likely to repeatedly purchase that product instead of switching to other alternative brands [84]. Customer satisfaction plays a pivotal role particularly in restaurant industry [85]. Han and Back [86] examined the satisfaction of guest in hotel industry. The findings of the study indicated that guest intention of re-patronage is connected with satisfaction with the services rendered to them. A recent study conducted by Rajput and Gahfoor [87] on factors triggers the revisit intention at fast food restaurant in Pakistan. They found that customer satisfaction with fast food restaurants is positively associated with revisit intention of customers. Han and Ryu [88] claimed that improvement in customer satisfaction is needed in order to increase the customer's visits in restaurants as satisfied customers are the loyal ones, a claim that has also been proved by many investigators $[89,90]$. Therefore, we can hypothesize that:

H7 Customer satisfaction has a positive influence on brand loyalty with fast food restaurants of Pakistan. 


\section{Social trust}

Trust is one of the most important synthetic forces within society [91]. Previously, social trust was the main concerned of researchers to understand how general trust is in people, its influence on attitudes and misanthropy but how it influences on consumer routine dealings/matter have been ignored yet [92]. It is defined as general "conviction on the honesty, truthfulness and faith in people." It does not suggest that individual place a trust on others because they know each other personally but it signifies a broader spectrum how people can be trusted in general and, without trust social bonding is unfeasible [93]. Numerous service organizations (in context of restaurant setting) are operating in society. There are two broad schools of thought who viewed social trust differently, first is, social-psychological thought believes on individualism while societal school of thought believes on collectivism. According to social-psychological school of thought, trust is an essential element of an individual personality trait $[94,95]$. This is because an individual learning about trust starts from their home, and this childhood socialization is changed with the passage of time as experience is gained [96]. Moreover, social trust is not only reliant on the reciprocity of experience, but also closely linked with the subjective feelings and the kind of the personality that individual have, as suggested by Uslaner [96]. Scholarly studies found that individual "belief in just world" is greatly associated with interpersonal trust and subjective well-being [97]. Faith in people and faith in the world are primary features of "belief in just world". The societal school of thought viewed that trust is not the property of an individual but that of a society [98, 99]. The focus of this approach is on how people evaluate the society in which they find themselves rather than their personality. Moreover, it is the top-bottom phenomenon that is developed by society and daily experience that recommends acting in a trusting and distrusting way [100]. Consumer who have been deceived in shops, exploited at workplace, served unjustly, betrayal, or lied by acquaintances on daily basis has low social trust and infers that people cannot be trusted in general which will ultimately affects their specific trust (use preexistent schemas) with restaurant [101]. Applying this notion into the context of this study, according to Boix and Daniel [18] that further describes the notion of Putnam [102], low-trust clientele remains satisfied with a restaurant when restaurant is failed to meet some standard of honesty at once. But if this could have happened more than once, he might have switched the restaurant, and this 'moral yardstick' further decreases his social trust. But the decision could be different if the customer possesses personality traits such as high tolerance level, faith on people, cooperative, optimistic, forgiver nature, etc. Boone et al. [103] found that specific personalities are strongly associated to an individual's behavior. In case of any negligence, a customer fully cooperates with a restaurateur and does not disappoint with the services [104]. The customer is still satisfied with the restaurant setting and plans to continue purchasing and talk favorably about the restaurant with others. Customer who possesses this sort of personality are less affected by the prevailing societal factors that lower the social trust of an individual but still believes that people can be trusted in general (his relational trust is less affected by his general trust). This trust could ultimately lead toward long-term commitment, greater share of wallet and positive word of mouth. Thus, we can hypothesize that:

H8 Social trust positively moderates the relationship between customer satisfaction and brand loyalty with fast food restaurants of Pakistan.

\section{Corporate social responsibility}

CSR is considered a universally recognized tool which benefits the food and beverage stakeholders, shareholders and communities Customers evaluate not only the food and service quality during their dining but also the CSR practices which they experience [105]. The positive experience in return gives competitive edge. Moreover, the clientele satisfaction with banquet includes both stakeholder relationships and CSR strategy on providing good service quality suggested by Woods' [106]. In this regard, formation of social programs and improving service quality are indeed strategy. The conceptualization of CSR developed by Carroll [107] based on four dimensions used in many studies is legal, economic, ethical and philanthropy. These studies viewed the relation of ethical CSR dimension with customer satisfaction and loyalty. The ethical practices of companies improve customer satisfaction and loyalty [108]. Integrity and price fairness are strongly connected with ethical practices. Many studies found a positive correlation between fairness, customer satisfaction and loyalty [109], while recent studies found that philanthropic CSR also has positive impact on both customer satisfaction and loyalty [110]. Philanthropic responsibility includes charity and volunteer work such as contributing donations to community or society and benevolence, accompanying with several benefits to society [107]. Szöcs [111] this research paper discusses about corporate philanthropy activities and corporate reputation. It reveals that very little systematic research exists regarding this effect. Social welfare activities influence the trust and brand loyalty and boosting the global reputation. However, it has created a labor management relation which creates satisfaction and loyalty throughout its 
workforce. According to Fombrun et al. [112], strategic philanthropists argue that philanthropy is not likely to generate direct economic returns, but it will create longterm competitive benefits for determining the firm value through intangible asset such as reputation and improves customer ties with organization. Not only the philanthropic activities improve the customer satisfaction and loyalty but also increase the company profitability. However, ethical responsibility encompasses the range of actions allowed or forbidden by society. It follows expectations concerning to what consumers, employees, community and share-holders consider as fair and just beyond legal constraints [107]. Fan [113], the author describes the value of good brand has been assessed in both legal and ethical manners by consumers. The brand reflects enormous impact not only to those who buy but on the whole society it carries its impact. Moreover, several studies viewed the impact of economic responsibility of CSR dimension on customer satisfaction and loyalty. Customer buying choice is positively influenced by CSR dimension of economic. Similarly, Rastini and Nurcaya [110] found a positive association of economic responsibility of CSR with customer satisfaction and loyalty. The attribute of economic CSR (price fairness) is highly correlated with satisfaction of customers and loyalty with brand. In addition, past studies also found a positive impact of legal CSR on customer satisfaction and loyalty as well. Conformity of consumer security and privacy laws were favorably linked with customer satisfaction and loyalty [114] because customers demonstrate confidence on companies that behave in accordance with legal laws [115]. Thus, we can hypothesize that:

H9 Corporate social responsibility positively moderates the relationship between customer satisfaction and customer loyalty with fast food restaurants of Pakistan.

\section{Methods}

\section{Instrument and measures}

The scale was adapted (slightly modified according to the context of current study) from indicators of extant studies which are food quality, service quality, restaurant atmosphere, restaurant location, price, variety of food, customer satisfaction, brand loyalty and social trust. All constructs were anchored using a Likert-scale format from $1=$ strongly disagree to $5=$ strongly agree A fiveitem scale was used to measure perceived food quality [116], a five-item scale was used to measure perceived service quality $[116,117]$, a four-item scale was used to perceive restaurant atmosphere [116, 117], a three-item scale was used to restaurant location [116], a three-item scale was used to measure price [116, 117], a three-item scale was used to measure variety of food [117], and a six-item scale was used to measure customer satisfaction [116]. Corporate social responsibility was divided into two dimensions, i.e., philanthropic responsibility and ethical-legal responsibility. The philanthropic responsibility was measured by 2 items and ethical-legal responsibility by 3 items (adapted from Brown and Dacin, [118]. Moreover, a seven-item scale was used to measure brand loyalty [119] and, further conceptualized into three dimensions as behavioral, affective and cognitive loyalty.

The standard survey question was asked in this study to measure/estimate the individual trustworthiness about society around them [120]. "Generally speaking, would you say that most people can be trusted or that you can't be too careful in dealing with people?' [121]. Moreover, the scale was adapted in the context of restaurant, drawn from societal school of thought and social-psychological school of thought: role of individual personality traits and role of society/social system in building individual general trust [122]. First, role of individual personality traits in building trust on society was gauged by proposed twoitem scale adapted from [121], a two-item scale of tolerance adapted from [121] and a two-item scale of general faith on people adapted from Rosenberg [123], whereas role of social system in building trust (restaurants are operating in society/part of society) was measured by proposed two-item scale on perception about current societal conditions adapted from [121] and a proposed two-item scale of social network of individuals adapted from [121]. For pretesting, the face validity of social trust scale was ensured by taking comments from group of experts/professors belonging to the area of marketing. The present study purified the scale by performing factor analysis. The validation of measurement model was initiated from exploratory factor analysis (EFA). Prior performing the exploratory factor analysis, the appropriateness of sample adequacy was determined through Kaiser-Meyer-Olikin $(\mathrm{KMO}=.880)$ and Bartlett's test of sphericity $(p=.000$, Chi square $=17,596.329, d f=1275)$. The KMO value should be above .60 [124], so we can proceed EFA after getting the satisfactory results [125]. We used principal component extraction method and Varimax rotation to comprehend the fundamental structure of measures [126]. EFA extracted one factor: social trust having eigenvalues 1.012 which explained the cumulative variance of $76.675 \%$.

The questionnaire was based on two sections. The first section was related to demographic characteristics of the respondents which comprised four close-ended questions. The second section was related to research constructs which contained 51 close-ended questions. It was pretested to highlight the ambiguity, ordering and phrasing of question or content validity $(n=100)$ and found 
that internal consistency of scale surpassed the cutoff level Cronbach alpha $>0.70$.

\section{Survey and sampling procedures}

The power analysis determined the minimum required sample size for Structural Equation Modeling (SEM) where $n=138$ in Daniel Soper Free Statistics Calculator version 4.0 for the present study. And it was carried out with number of latent variables $n=8$, number of observed variables $n=44$, power level $=0.8$, probability $=0.05$ and effect size $=0.15$. In addition to this, the minimum suggested sample size for SEM is $n=100$ [127]. Moreover, we also used G*Power 3.1 software for sample size determination [128]. The results indicated that minimum sample size of 55 was required to achieve a power of 80 percent with medium effect size (0.5).

The data were collected on convenient basis and approached the participants through self-administered located at four big cities of Punjab province (i.e., Islamabad, Lahore, Multan and Faisalabad) and approached other province participants through online survey, via posting a web-link of Google docs among different groups on Facebook, Instagram and WhatsApp. The structured questionnaire commenced with an openended question following the critical incident method based on the survey research of Seckler and Klaus [129]. The open-ended statement asked respondents to read a statement before moving ahead to fill out the questionnaire: "Please think a moment that you are feeling satisfied when visit fast food restaurant. Try to explain your experience with the fast food restaurant performance as you recall it." The purpose of this question was to receive the descriptions of consumer experiences with fast food restaurants. The data collected around a period of 8 weeks, between November and December 2019, and completing a questionnaire took approximately 15-20 min. A total of four hundred and fifty questionnaires were distributed among the respondents. A total of 300 self-administered questionnaires were dispersed to the students of different universities and general public as well. Out of the 300 self-administered questionnaires, 225 questionnaires were received back. A total of 225 questionnaires were completed in all respects, while the remaining seventy-five incomplete questionnaires were discarded. The remaining responses were obtained through web-based survey and resulting in a total of 400 responses.

The convenience sampling was used for data collection, as this sampling technique has been questioned to generalize their findings. Past studies successfully employed this method for data collection [130, 131]. However, convenience sampling is appropriate under two conditions: first, for exploratory studies; second, measurement items got relevancy with the participants [132]. The authors employed measurement items that pertain to the respondents; therefore, our present study satisfies the conditions to validate the use of convenience sampling.

\section{Demographic characteristics}

Table 1 shows the demographic characteristics of the respondents. Female respondents are greater in numbers than male respondents. The sample of this study consists of 400 people, of which 222 (55.5\%) were women and 178 $(44.5 \%)$ were men. The middle age group 31-45 years had a higher representation $(41.75 \%)$ than the other age groups of $18-30$ years (38.25\%) and above 45 years (20\%). The percentage of middle age groups is higher than other two groups because majority of this age group was having employment or businesses as evident from the collected data. As regards the profession, service respondents had major proportion (34.5\%) in comparison to students (24\%), businessman (13.25\%), unemployed (13.25\%) and others (15\%). Respondents were also asked about the restaurants they visit frequently. Three possible options were given to them, i.e., McDonalds, KFC and others (local/national). The results indicate that majority of the respondents visited restaurants other than McDonalds and KFC with a higher percentage of $41.75 \%$, while the remaining $32.5 \%$ and $26 \%$ of the respondents visited KFC and McDonalds, respectively. Moreover, the findings also revealed that over half percentage $72 \%$ of Pakistani

Table 1 Demographic characteristics of respondents

\begin{tabular}{ll}
\hline Demographic profile of participants (\%) & \\
\hline Gender & \\
Female & 55.50 \\
Male & 44.50 \\
Age & \\
18-30 years & 38.25 \\
31-45 years & 41.75 \\
Above 45 & 20.00 \\
Profession & \\
Student & 24.00 \\
Service & 34.50 \\
Business & 13.25 \\
Unemployed & 13.25 \\
Others & 15.00 \\
Facility & \\
McDonalds & 26.00 \\
KFC & 32.50 \\
Others & 41.75 \\
Social trust & \\
Most people can be trusted & 28.00 \\
Need to be careful & 72.00 \\
\hline
\end{tabular}


inhabitants have low trust about society around them (need to be careful) followed by $28 \%$ having high social trust (e.g., high generalized trust on society).

\section{Common method variance}

The data were collected from single source at a single point in time; common method variance might be an issue in the data, though Harman's single-factor test was used [133]. As common method was opted in study, we checked dubious amount of covariance among the variables. For this, exploratory factor analysis (EFA) was performed for all the indicators of the variables, which demonstrates that nine components cumulatively explained $75.046 \%$ of variance among the constructs. The first factor explained variance of $18.431 \%$, second factor accounts for $12.609 \%$, and third $11.207 \%$, fourth, fifth, sixth, seventh, eighth and ninth components explained variance by $8.232 \%, 7.781 \%, 5.598 \%, 4.687 \%, 4.107 \%$ and $2.393 \%$, respectively. The common method variance (CMV) is not an issue in our data, though not even a single component is held accountable for large sum of variance.

\section{Measurement model}

The study performed statistical analysis by using SPSS Amos Graphics version 21. We followed two-stage procedure of Anderson and Gerbing's [127] for statistical analysis in Structural Equation Modeling (SEM). By employing this approach, we initially analyzed the reliability and validity by the measurement model, and later we perform path analysis by the structural model. The basic premise behind using this approach, prior testing the structural association between constructs, is that we first assessed the reliability and validity of latent constructs (Table 2).

Confirmatory factor analysis was used to assess the reliability and validity of unobserved variables. The output generated by confirmatory factor analysis indicates a good model fitness $\left(\chi^{2}=161.223, d f=915 ; \chi^{2} / d f=1.772\right.$, $\mathrm{RMR}=0.048, \quad \mathrm{IFI}=.951, \quad \mathrm{TLI}=.944, \quad \mathrm{CFI}=0.950$, $\mathrm{PCFI}=.840, \mathrm{PNFI}=.790$; RMSEA $=0.044)[134]$. The fit indices illustrate that unobserved variables are perfectly measured by their items. Reliability was tested from the scores of Cronbach alpha and composite reliability (CR). Table 3 shows that all unobserved constructs CR scores are ranging from 0.89 to 0.96 , and they are above the cutoff level .70 [135] and $\alpha$ scores also exceed the recommended threshold level $>0.70$ [135] ranging from 0.85 to 0.94 . With regard to convergent validity, we followed Fornell and Larcker [136] approach; all items should have factor loading score greater than 0.70 and should be significant. The table vividly exhibits that all items have factor loadings above 0.70 with loadings ranging from
$0.788^{* * * *}$ to $0.951^{* * *}$ and significant at $p<0.001$. The average variance extracted is above the suggested threshold $>0.50$ with values ranging $0.51-0.88[135,136]$ and thus got the convergent validity [135]. We ensured the discriminant validity by employing two tests; first, the square root of average variance extracted or diagonal value should be greater than the correlation among the constructs at the resultant rows and columns [136], and another, the correlation midst the variables shouldn't exceed 0.85 [137].

\section{Structural model \\ Measurement of research model fitness}

The results of measurement model indicate a good model fitness. The structural model was tested in SPSS Amos Graphics version 21.0. The results of structural model demonstrate goodness of fit $\left(\chi^{2} / d f=2.201 \mathrm{CFI}=0.97\right.$; $\mathrm{NFI}=0.95 ; \quad \mathrm{IFI}=0.97 ; \quad \mathrm{TLI}=0.96 ; \quad$ AGFI $=0.85 ;$ $\mathrm{PCFI}=0.84$; $\mathrm{RMSEA}=0.03$; $\mathrm{SRMR}=0.05$ ). The fit indices are in reasonable and acceptable range [134, 138]. Thus, these results demonstrate that structure of proposed research model efficiently illustrates the association between latent constructs [135].

\section{Hypotheses testing}

Structure Equation Modeling (SEM) technique with maximum likelihood estimation was employed to test the hypothesized relationship. After following first step of Anderson and Gerbing [127] approach of statistical analysis, eventually we carried out second step and performed path analysis by the structural model. For this, we first plaid multicollinearity in SPSS which is an important assumption prior to test the research model in SEM. Table 4 indicates that all predictor variables had variance inflation factor (VIF) ranging from 1.044 to 2.572. It shows that no multicollinearity exists among the predictor variables as they satisfy the suggested criteria $<3$. The path coefficients are displayed in Fig. 1. The results of hypothesized relationship are presented in Table 4. As Table 4 demonstrates that food quality has positive effect on customer satisfaction $(\beta=0.378, t=27.998, \mathrm{p}<0.001)$, we accepted H1. Service quality has profound significant effect on customer satisfaction $(\beta=0.303, t=21.877$, $p<0.001)$; thus, we accepted H2. Restaurant atmosphere has gained support as it has positive significant effect on customer satisfaction $(\beta=0.227, t=18.619, p<0.001)$, so, we accepted H3. Restaurant location $(\beta=0.121, t=7.994$, $p<0.001$, price $(\beta=0.151, t=12.055, p<0.001)$ and variety $(\beta=0.102, t=10.358, p<0.001)$ exerts a positive significant impact on customer satisfaction; therefore, $\mathrm{H} 4$, $\mathrm{H} 5$ and $\mathrm{H6}$, respectively, gained support. Customer satisfaction exerts robust effect on brand loyalty; therefore, H7 is supported. 
Table 2 Measurement model

\begin{tabular}{|c|c|c|c|}
\hline Constructs & Items & Statements & SFL \\
\hline \multicolumn{4}{|c|}{$\begin{array}{l}\text { Please rate the following constructs; food quality, service quality, restaurant location, restaurant atmosphere, price and variety of food of your favorite } \\
\text { restaurants }\end{array}$} \\
\hline \multirow{4}{*}{$\begin{array}{l}\text { Food quality } \\
a=.921, \mathrm{CR}=.914, \mathrm{AVE}=.727 \sqrt{ } \mathrm{AV} E=.852\end{array}$} & $\mathrm{~F} 1$ & Taste & $0.831^{* * *}$ \\
\hline & F2 & Fresh and rich flavor & $0.901^{* * *}$ \\
\hline & F3 & Nutritional content & $0.865^{* * *}$ \\
\hline & F4 & Eye appealing & $0.813^{* * *}$ \\
\hline \multirow{4}{*}{$\begin{array}{l}\text { Service quality } \\
a=.907, \mathrm{CR}=.899, \mathrm{AVE}=.690, \sqrt{ } \mathrm{AVE}=.831\end{array}$} & SQ1 & Quickness of service line & $0.744^{* * *}$ \\
\hline & SQ2 & Order fulfillment time & $0.817^{* * *}$ \\
\hline & SQ3 & Attentive staff & $0.901^{* * *}$ \\
\hline & $\mathrm{SQ} 4$ & Courteous & $0.855^{* * *}$ \\
\hline \multirow{3}{*}{$\begin{array}{l}\text { Restaurant atmosphere } \\
a=.892, \mathrm{CR}=.895, \mathrm{AVE}=.510, \sqrt{ } \mathrm{AVE}=.714\end{array}$} & RA1 & Cleanliness & $0.861^{* * *}$ \\
\hline & RA2 & Comfortable environment & $0.927^{* * *}$ \\
\hline & RA4 & Layout & $0.788^{* * *}$ \\
\hline \multirow{3}{*}{$\begin{array}{l}\text { Restaurant location } \\
a=.895, \mathrm{CR}=.893, \mathrm{AVE}=.73, \sqrt{ } \mathrm{AVE}=.857\end{array}$} & $\mathrm{RL} 1$ & Convenient location & $0.850^{* * *}$ \\
\hline & $\mathrm{RL} 2$ & Short walking distance & $0.798^{* * *}$ \\
\hline & RL3 & Parking convenience & $0.921^{* * *}$ \\
\hline \multirow{3}{*}{$\begin{array}{l}\text { Price } \\
a=.898, \mathrm{CR}=.901, \mathrm{AVE}=.753, \sqrt{ } \mathrm{AVE}=.867\end{array}$} & P1 & Good value for the price charged & $0.864^{* * *}$ \\
\hline & P2 & Appropriate portion size & $0.810^{* * *}$ \\
\hline & P3 & Reasonable price item & $0.926^{* * *}$ \\
\hline \multirow{3}{*}{$\begin{array}{l}\text { Variety of food } \\
a=.884, C R=.890 \\
\text { AVE }=.730, \sqrt{ } \text { AVE }=.851\end{array}$} & V1 & Food choices (menu) & $0.951^{* * *}$ \\
\hline & V2 & Ready to deliver (in stock) & $0.803^{* * *}$ \\
\hline & V3 & $\begin{array}{l}\text { Special meals and promotion are offered } \\
\text { frequently. }\end{array}$ & $0.801^{* * *}$ \\
\hline \multirow{4}{*}{$\begin{array}{l}\text { Customer satisfaction } \\
a=.939, \mathrm{CR}=.939 \\
\mathrm{AVE}=.795, \sqrt{ } \mathrm{AVE}=.891\end{array}$} & CS3 & I'm satisfied with restaurant atmosphere. & $0.884^{* * *}$ \\
\hline & CS4 & I'm satisfied with restaurant location. & $0.889^{* * *}$ \\
\hline & CS5 & I'm satisfied with the price range of restaurant. & $0.924^{* * *}$ \\
\hline & CS6 & $\begin{array}{l}\text { I'm overall satisfied with the quality of restau- } \\
\text { rant service. }\end{array}$ & $0.869^{* * *}$ \\
\hline \multirow{7}{*}{$\begin{array}{l}\text { Brand loyalty } \\
a=.960, \mathrm{CR}=.960 \\
\mathrm{AVE}=.883, \sqrt{ } \mathrm{AVE}=.939\end{array}$} & BL1 & $\begin{array}{l}\text { I have been with my favorite fast-food restau- } \\
\text { rant for a long time. }\end{array}$ & $0.866^{* * *}$ \\
\hline & BL2 & $\begin{array}{l}\text { I am planning to continue relying on my } \\
\text { favorite fast food restaurants for a longer } \\
\text { period. }\end{array}$ & $0.882^{* * *}$ \\
\hline & BL3 & $\begin{array}{l}\text { If restaurant were to raise their prices, I would } \\
\text { continue visit the same restaurant }\end{array}$ & $0.893^{* * *}$ \\
\hline & $\mathrm{ALI}$ & $\begin{array}{l}\text { Once I get used to a fast-food restaurant, I } \\
\text { hate to switch }\end{array}$ & $0.883^{* * *}$ \\
\hline & AL2 & $\begin{array}{l}\text { I have developed some sort of emotional con- } \\
\text { nection with my favorite fast-food restaurant }\end{array}$ & $0.889^{* * *}$ \\
\hline & CL1 & $\begin{array}{l}\text { When I decide to stay with a fast-food restau- } \\
\text { rant, I make sure that it is a competent one }\end{array}$ & $0.873^{* * *}$ \\
\hline & $\mathrm{CL} 2$ & $\begin{array}{l}\text { Client loyalty in fast-food restaurants is based } \\
\text { on good experiences }\end{array}$ & $0.873^{* * *}$ \\
\hline $\begin{array}{l}\mathrm{CSR} \\
a=.951, \mathrm{CR}=.948 \\
\mathrm{AVE}=.786, \sqrt{\mathrm{AVE}}=.886\end{array}$ & ELCSR1 & $\begin{array}{l}\text { It behaves ethically/honestly with its custom- } \\
\text { ers }\end{array}$ & $0.912^{* * *}$ \\
\hline
\end{tabular}


Table 2 (continued)

\begin{tabular}{|c|c|c|c|}
\hline Constructs & Items & Statements & SFL \\
\hline & ELCSR2 & $\begin{array}{l}\text { It always respects the norms defined in the } \\
\text { law when carrying out its activities }\end{array}$ & $0.940^{* * *}$ \\
\hline & ELCSR3 & $\begin{array}{l}\text { It respects the ethical principles in its relation- } \\
\text { ships and it gives priority over achieving } \\
\text { superior economic performance }\end{array}$ & $0.896^{* * *}$ \\
\hline & PLCSR1 & $\begin{array}{l}\text { It directs part of its budget to donations for } \\
\text { social causes }\end{array}$ & $0.803^{* * *}$ \\
\hline & PLCSR2 & $\begin{array}{l}\text { It committed toward society by improving } \\
\text { the welfare of the communities in which it } \\
\text { operates }\end{array}$ & $0.876^{* * *}$ \\
\hline \multirow[t]{11}{*}{$\begin{array}{l}\text { Social trust } \\
a=.937, \mathrm{CR}=.935 \\
\mathrm{AVE}=.611, \sqrt{ } \mathrm{AVE}=.782\end{array}$} & $\begin{array}{l}\text { Generally speaking, would you say that most } \\
\text { people can be trusted or that you can't be } \\
\text { too careful in dealing with people? }\end{array}$ & & \\
\hline & Per1 & $\begin{array}{l}\text { When I face any problem in restaurant, it } \\
\text { couldn't influence me negatively. }\end{array}$ & $0.754^{* * *}$ \\
\hline & Per2 & $\begin{array}{l}\text { When I face any problem in restaurant, it } \\
\text { couldn't lead me to untrustworthiness. }\end{array}$ & $0.753^{* * *}$ \\
\hline & $\mathrm{T} 1$ & $\begin{array}{l}\text { I can tolerate if restaurant doesn't meet stand- } \\
\text { ard of honesty once. }\end{array}$ & $0.722^{* * *}$ \\
\hline & $\mathrm{T} 2$ & $\begin{array}{l}\text { I can tolerate if restaurant doesn't meet its } \\
\text { delivered service promise once. }\end{array}$ & $0.785^{* * *}$ \\
\hline & F1 & $\begin{array}{l}\text { I believe, today's restaurants are more inclined } \\
\text { to accommodate their customers/co- } \\
\text { operative. }\end{array}$ & $0.753^{* * *}$ \\
\hline & $\mathrm{F} 2$ & $\begin{array}{l}\text { I am careful when dealing with fast food } \\
\text { operators }\end{array}$ & $0.743^{* * *}$ \\
\hline & SC1 & I am satisfied with safety standards (security) & $0.788^{* * *}$ \\
\hline & SC2 & I feel safe when I dine in my restaurant. & $0.825^{* * *}$ \\
\hline & SN1 & $\begin{array}{l}\text { I mostly visit restaurants recommended by } \\
\text { my friends. }\end{array}$ & $0.783^{* * *}$ \\
\hline & SN2 & $\begin{array}{l}\text { My trust on restaurant is affected by my friend } \\
\text { opinion. }\end{array}$ & $0.780^{* * *}$ \\
\hline
\end{tabular}

SFL, standardized factor loadings; $a$, Cronbach alpha; $C R$, composite reliability; $A V E$, average variance extracted; $\sqrt{ }$ AVE, discriminant validity

*** $p<0.001$

Table 3 Discriminant validity

\begin{tabular}{|c|c|c|c|c|c|c|c|c|c|c|c|c|c|}
\hline Constructs & Mean & SD & VIF & 1 & 2 & 3 & 4 & 5 & 6 & 7 & 8 & 9 & 10 \\
\hline $\mathrm{FQ}$ & 3.87 & 1.05 & 1.925 & .852 & & & & & & & & & \\
\hline SQ & 3.96 & 1.01 & 1.935 & $.669^{* *}$ & .831 & & & & & & & & \\
\hline RA & 3.89 & 1.11 & 1.110 & $.197^{* *}$ & $.257^{* *}$ & .714 & & & & & & & \\
\hline$R L$ & 3.77 & 1.14 & 1.178 & $.230^{* *}$ & $.222^{* *}$ & $.141^{* *}$ & .857 & & & & & & \\
\hline$P R$ & 3.85 & 1.08 & 2.572 & $.268^{* *}$ & $.233^{* *}$ & $.210^{* *}$ & $.315^{* *}$ & .867 & & & & & \\
\hline VR & 3.85 & 1.04 & 2.311 & $.177^{* *}$ & $.136^{* *}$ & $.159^{* *}$ & $.150^{* *}$ & $.743^{* *}$ & .851 & & & & \\
\hline CS & 3.84 & .859 & 1.215 & $.358^{* *}$ & $.344^{* *}$ & $.138^{* *}$ & $.157^{* *}$ & $.201^{* *}$ & $.170^{* *}$ & .891 & & & \\
\hline$B L$ & 4.06 & .924 & 1.191 & $.225^{* *}$ & $.172^{* *}$ & $.128^{* *}$ & $.121^{* *}$ & $.368^{* *}$ & $.322^{* *}$ & $.166^{* *}$ & .939 & & \\
\hline CSR & 4.03 & .832 & 1.044 & 0.051 & 0.053 & 0.061 & 0.003 & -0.08 & 0.006 & 0.060 & 0.068 & 0.886 & \\
\hline ST & 3.61 & .840 & 1.057 & -.039 & -.097 & .032 & -.015 & -.040 & .033 & $-.141^{* *}$ & .001 & -.003 & .782 \\
\hline
\end{tabular}

The bold digits in the diagonal are square root of AVE

$1=$ food quality $(\mathrm{FQ}), 2=$ service quality $(\mathrm{SQ}), 3=$ restaurant atmosphere $(\mathrm{RA}), 4=$ restaurant location (RL), $5=$ price $(\mathrm{PR}), 6=$ variety $(\mathrm{VR}) 7=$ customer satisfaction $(\mathrm{CS})$, $8=$ brand loyalty (BL), $9=\mathrm{CSR}, 10=$ social trust (ST)

** $p<0.01$ 
Table 4 Statistics of hypotheses testing

\begin{tabular}{lccc}
\hline Paths & Standardized estimates & T-statistics & Relationship \\
\hline H1 food quality $\rightarrow$ customer satisfaction & $.378^{* * *}$ & 27.998 & Supported \\
H2 service quality $\rightarrow$ customer satisfaction & $.303^{* * *}$ & 21.877 & Supported \\
H3 restaurant atmosphere $\rightarrow$ customer satisfaction & $.227^{* *}$ & 18.619 & Supported \\
H4 restaurant location $\rightarrow$ customer satisfaction & $.121^{* *}$ & 7.994 & Supported \\
H5 price $\rightarrow$ customer satisfaction & $.151^{* * *}$ & 12.055 & Supported \\
H6 variety $\rightarrow$ customer satisfaction & $.102^{* * *}$ & 10.358 & Supported \\
H7 customer satisfaction $\rightarrow$ brand loyalty & $.70^{* * *}$ & 19.621 & Supported \\
H8 customer satisfaction $\times$ social trust $\rightarrow$ brand loyalty & $.109^{*}$ & 2.181 & Supported \\
H9 customer satisfaction $\times$ CSR $\rightarrow$ brand loyalty & -.138 & 1.772 & Unsupported \\
\hline
\end{tabular}

${ }^{* * *} p<0.001,{ }^{* *} p<0.01,{ }^{*} p<0.05$

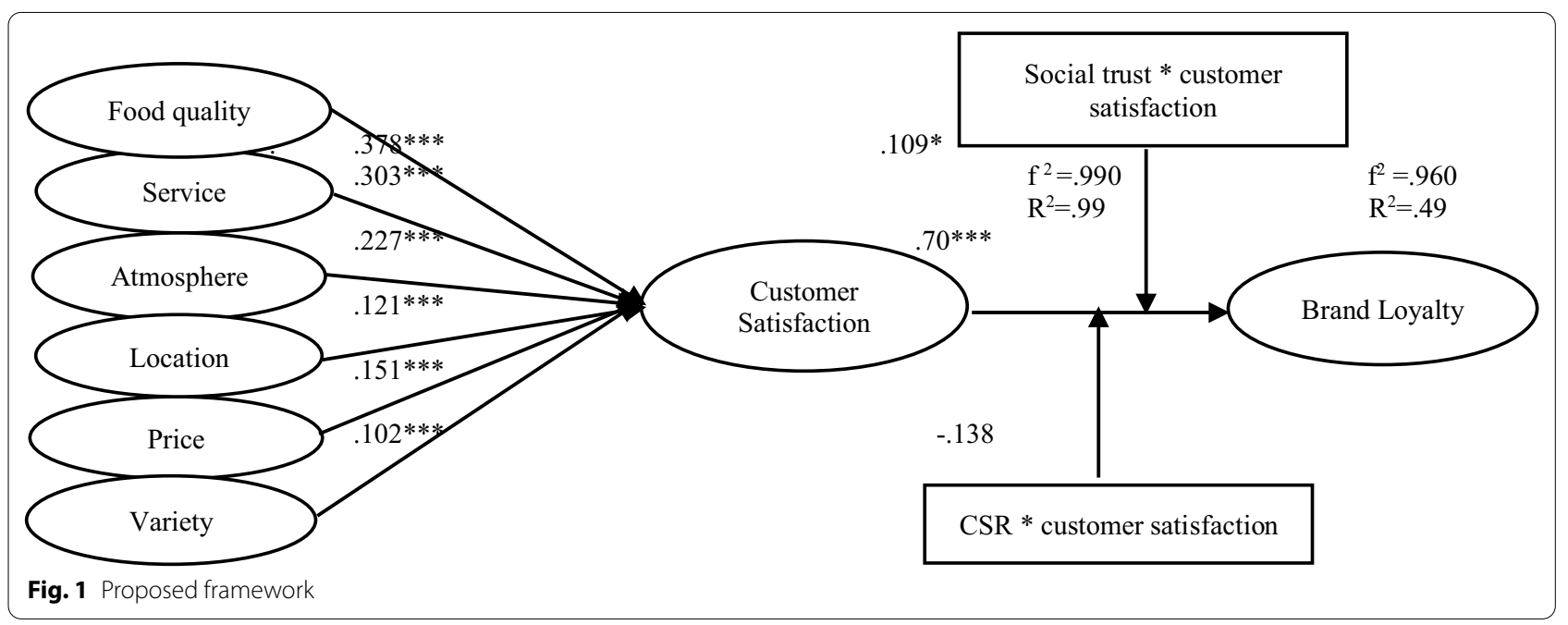

Figure 1 demonstrates the explanatory power $\left(R^{2}\right)$ of outcome constructs. The predictive power of $R^{2}$ explained the total variance in outcome variable due to predictor variables. The results show $99 \%$ of variance in customer satisfaction and $49 \%$ of variance in brand loyalty. Our $R^{2}$ results are above the suggested threshold level of Falk and Miller [140] $>10 \%$. On the basis of recommendation of Cohen's [139], we checked the ample effect size $\left(f^{2}\right)$ of our model, small size effect size 0.02 , medium effect size 0.15 and large effect size 0.35 . We found that both customer satisfaction and brand loyalty have large effect size $\left(f^{2}=0.99\right.$ and $\left.f^{2}=0.960\right)$.

\section{Moderation and simple main effects}

To test the effects of moderator (social trust) through interaction effects, we used IBM SPSS version 23.0. Using the moderation step by step, we examined first the direct effect of predictor variable on outcome variable and then main direct effects of interaction of moderators with predictor variable on outcome variable. We found that direct effects of customer satisfaction on brand loyalty are positively significant $(F=384.008, p<0.001)$, and main direct effects of customer satisfaction and social trust (customer satisfaction * social trust) on brand loyalty are also positively significant $(\beta=.109, t=2.181$, $p<0.05)$. Moreover, after getting the significant interaction effects, we followed Aiken et al. [141] suggestions to examine the nature of interactions by allocating the data of moderators into two groups'-high and low-by using dummy variable. We observed the simple main effects of customer satisfaction on brand loyalty at both high and low level of social trust. We found that customer satisfaction has positive significant impact on brand loyalty when customer social trust is high $(\beta=0.082, t=3.165$, $p<0.001$ ), and customer satisfaction has an insignificant impact on brand loyalty when customer societal trust is low $(\beta=0.024, t=1.096, p>0.01)$. Therefore, social trust positively moderates the relationship at higher level of social trust, and we accept H8. Moreover, we found that customer satisfaction has insignificant impact on brand loyalty when CSR is high $(\beta=-.390, t=1.468, p>0.05)$ and low $(\beta=-.184, t=1.201, p>0.05)$. Therefore, CSR 
didn't moderate the relationship of CSR and brand loyalty; therefore, we reject $\mathrm{H} 9$.

\section{Discussion Major findings}

Prior studies on restaurant setting conferred that customer satisfaction are vital determinant of brand loyalty [142]. In the context of fast food industry, restaurant stimuli play a crucial role in creating customer satisfaction which in turn establishes brand loyalty [143, 144]. In Pakistan, fast food industry is rapidly growing over last decade. They are found in every nook and corner. In the salad day of millennium, brand loyalty is a big challenge for fast food operators. Thus, this study on brand loyalty adds noteworthy value to restaurant industry. The study develops an integrative model on predictor and outcome of customer satisfaction drawn from previous literature.

\section{Restaurant stimuli}

Our findings suggest that restaurant stimuli such as food quality, service quality, restaurant atmosphere, restaurant location, price and variety of food have profound impact on customer satisfaction. These findings are in line with [87] empirical studies. It demonstrates that these stimuli are crucial for fast food restaurant customers and have paramount impact on their satisfaction. Our study findings also verify that customer satisfaction has significant effect on brand loyalty. This result also completely agrees with prior empirical research findings [81, 142]. At this point, customers decide on either re-patronage or discontinuity. Moreover, the findings revealed that customer satisfaction acts as a strong mediator between restaurant stimuli and consumer behavioral intentions. Any negligence in the aforementioned stimuli hurts the customer satisfaction and ultimately brand loyalty with restaurants. In addition to this, the results demonstrate that $\left(\beta=0.70^{* * * *}\right) 70 \%$ satisfied customer turns them to be brand loyal.

\section{Social trust}

Furthermore, our result is about social trust which suggests us that Pakistani inhabitants social trust is not so high as greater percentage $(72 \%)$ of people believe that they need to be careful when dealing with others and only $28 \%$ believe that people can be trusted in general. This finding is consistent with World Value Survey Report which indicated that only $22.2 \%$ Pakistani citizens believed that people can be trusted in general, whereas $73.8 \%$ respondents believed that people needs to be careful while dealing with others $[145,146]$. Moreover, our results on moderating variable social trust suggest that consumer social trust positively moderates the relationship at higher level between customer satisfaction and brand loyalty. Consumer relies on their preexistent schemas of having beliefs about the general trustworthiness of people, and thus, this general trust (social trust) has an impact on their specific and relational trust [101] with their restaurants. Based on the conceptualizations of societal school of thought, findings suggest that the consumers who possess low social trust hold a view that people cannot be trusted and in general tend to switch to other restaurants easily, as once or twice get dissatisfied with the services rendered by particular restaurant because their specific trust gets affected due to general trust. For example, applying this notion in the context of restaurant sector, customers may have come across experiences from different sources like friends (share a pic found bug in food), news or TV channels break a news that a particular restaurant is being sealed due to providing unhygienic food, using sub-standards products (dead meat, poor quality oil etc.), untidy kitchen (cockroaches, mouse are found there) which effect already build up specific/relational trust (faith on people) on quick meal restaurants (operating in society) and in turn affect their satisfaction and brand loyalty with their mostly visited restaurants. Shifting toward social-psychological school of thought, customers respond to diverse scenarios (like mistakenly threw a drink/food on customer, find a bug in food etc.) affected by the customer personality traits (tolerance, understanding, cooperative, optimistic, low anxiety, forgiver nature, etc.) which in turn effects brand loyalty [145]. Thus, the response to any situation in a restaurant setting is decided by customer personality traits (possessing these positive personality traits leads to high generalized trust) along with the trust gained from the society [16]. Our findings suggest that customer who hold positive social trust have strong bonding with restaurants and make maximum effort that his relational trust will not get affected due to his general trust.

\section{Corporate social responsibility}

Finally, our last result is about corporate social responsibility which is beyond our expectations, suggesting that it didn't affect the bonding between brand loyalty and customer satisfaction. The results didn't support our hypothesis so we reject H9. In Pakistan the results are different from the studies conducted abroad; here customers don't evaluate their restaurants in terms of CSR. The majority of people are not aware about the term CSR. People's primary expectation is to provide a good food, service, atmosphere, etc., and yet they are not concerned that restaurant is serving back our community in which it operates or engage in social responsibility. The other reason behind this is that the concept of CSR is not fully emerged in Pakistan Fast Food industry; international fast food chains adopt CSR, but still many national 
and local fast food restaurants don't recognize the importance of CSR and reluctant to implement. Results reveal that majority of customers usually visit the national or local restaurants where CSR is not fully practiced. That's why the sort of bonding that customer holds with restaurants is not affected by CSR.

\section{Conclusion}

The present study found that restaurant stimuli food quality, service quality, restaurant atmosphere, restaurant location, price and variety of food are crucial factors that significantly influence customer satisfaction and ultimate brand loyalty. Our present study contributes to the literature (of brand loyalty, customer satisfaction, social trust) by presenting an integrative model of predictors (restaurant stimuli) and outcomes (brand loyalty/continue to purchase) of customer satisfaction and addressing how factors are affecting the brand loyalty or in terms of re-patronage. The findings suggest the importance of restaurant stimuli in developing customer satisfaction which in turn creates brand loyalty. CSR doesn't moderate the relationship between loyalty and satisfaction. Moreover, we found the moderating effect of social trust on the relationship between customer satisfaction and brand loyalty. Moreover, these associations recommend that a consumer's general trust on his society affects his satisfaction which leads to behavioral intentions. We find that customer brand loyalty gets negatively affected due to having low social trust on their society and vice versa. Our proposed model offers a detailed investigation and elucidation of factors that are crucial in the eye of customers, and how consumer social trust affects his relationship with restaurants which have not yet been examined. This study provides valuable insights into fast food restaurants, restaurant managers and government. By focusing on our findings and recommendations, such as evaluating clients' feedback on continuous basis, asking for suggestions, keeping an eye on complaint boxes, never ignoring clients' complaints, keeping an eye on the changing needs of customer etc., restaurant's will benefit by augmenting the brand loyalty. For government, this study gives insight that customer brand loyalty and customer satisfaction are influenced to some extent by his societal trust; they should take some measures and devise strategies to increase the individual general trust on society which has a positive ultimate effect on the customer routine dealings/matters.

\section{Theoretical implications}

Our study is first to empirically examine the integrative model of predicting customer satisfaction outcome, though the predictors and outcome of satisfaction are not new. Moreover, our study theoretically contributes to the literature of customer satisfaction, brand loyalty and social trust. The extant literature has comprehensively examined the drivers of customer satisfaction [147] and predictor of brand loyalty $[81,142]$. Numerous studies have been carried out in context of fast food industry loyalty [148], but effects of integrative model had not been explored yet. Therefore, it contributes to the literature by examining the effects of restaurant stimuli (food quality, service quality, atmosphere, location, price and variety of food) on customer satisfaction and on brand loyalty through customer satisfaction (indirect effect). In the context of fast food industry, the extant literature examined the role of brand trust in establishing brand loyalty [15]. But the role of customer social trust affecting the brand loyalty has not been examined before. Therefore, we incorporate social trust as a moderator in our proposed model to offer new insight and make worthy contribution in the literature of social trust. In particular, the consumer social trust affects his connection with restaurant because customer moral yardstick of general trust on society affect his specific trust on restaurant, but extant literature has been overlooked.

\section{Practical implications}

The study finds that restaurant stimuli have a positive effect on customer satisfaction and ultimately on brand loyalty. On the basis of these findings, the study gives some recommendations to fast food operators that could be useful to develop and maintain long lasting relationship with customers as well as sustainable growth in a competitive market. The customer's prime concern is not only to get good quality of food but also good services and a variety of food in an aesthetic atmosphere. It is thus essential to provide good services and to reduce time between order placement and order fulfillment, to provide quick service and to give respect to customers. Moreover, there is much need to provide serenity and sound environment and also to work harder to make it more charming and to improve interior as well as outer look. All foodstuff should be available at a competitive price; therefore, management needs to revise their processes in order to cut down the cost. Fast food operators should keep a close eye on the changing needs of the customer, take feedback from customers on a regular basis. With regard to social trust, fast food operators ensure the safety standards of foods, disclose the menu information and permit to often visit the kitchen; in this way, it strengthens their specific trust and general trust as well. The study also gives insights into the government about the social trust that have impact on consumer connections with a particular restaurant. In the context of the restaurant, the government augments the customer general trust to society, by activating the Pakistan Food 
Testing Authority to constantly regulate the food safety standards in restaurants and permanently close those restaurants that play with the health of people by using sub-standard products.

\section{Limitations and future directions}

No study exists without limitations. Our study underlies the following limitations and offers directions to future researchers. First, the study used cross-sectional data, and future research can employ longitudinal data or could use another design like experimental design. Second, this study context is general, and future study could categorize restaurants into upscale, medium-scale and low-scale restaurants and assess the differences. Third, due to cultural differences, diverse scenarios of competition, level of social trust and consumer behavior, we recommend future research to cross-validate the proposed model in other developing countries or in different contexts generalize the results of the present study. Fourth, future scholars could consider WOM (positive and negative word of mouth) as a moderator to investigate how it influences the relationship of customer satisfaction and brand loyalty. Fifth, though the sample size of present study is small, the findings of moderator CSR couldn't be different with large sample. Finally, the present study is limited to the fast food industry; measure the attributes affecting brand loyalty through customer satisfaction, to augment the robustness of model it can apply to other service industries like the hotel industry.

\section{Abbreviations \\ CSR: corporate social responsibility; WOM: word of mouth.}

\section{Acknowledgements}

The first author Sara Javed and Md. Salamun Rashidin is thankful to University of International Business and Economics (UIBE) authorities for the research fund and financial support during my Masters and $\mathrm{PhD}$ research studies.

\section{Authors' contribution}

This research was contributed by three authors. SJ first author and MR second author made conceptualization, analysis, investigation and data collection; then third author helps to fix method and review the final review and editing. Regarding funding, Professor WJ (third author) is managed. "SJ and MR contributed to conceptualization; WJ provided methodology and performed supervision; SJ provided software and performed visualization; SJ, MR and WJ performed validation; SJ and MR contributed to project administration, formal analysis, investigation, resources, data curation and writing - original draft preparation; WJ performed writing - review and editing; WJ, SJ and MR contributed to funding acquisition; WJ is the initials of the author. All of the authors have read and approved the manuscript and agreed both to be personally accountable for the author's own contributions.

\section{Authors' information}

Md. Salamun Rashidin is a Ph.D. Scholar in School of International Trade and Economics at University of International Business and Economies (UIBE). His Major is Business Economics. His research field is International Trade, E-Commerce, World Economy, Marketing Management fields. He published lots of research paper in the field of international Trade, Marketing and Management journal.
Sara Javed is a Ph.D. Scholar in the Department of Marketing at University of International Business and Economies (UIBE). Her research field is Marketing Management, Trade Management, e-Marketing, and Supply Chain Management. She published many papers in the field of marketing.

Dr. Wang Jian is Professor in School of International Trade and Economics at University of International Business and Economics as well as Cross border E-commoner Vice president at Alibaba group, China. He is National Excellent Teacher in China. His research area is international trade practices and Ecommerce. He has already published dozens of books and articles in the top journal in China.

\section{Funding}

The Fundamental Research Funds for the Central Universities" in UIBE of China (CXTD10-11), University of International Business and Economics of China and the National Social Science Foundation of China (17ZDA098).

\section{Availability of data and materials}

Not included but available on request.

\section{Competing of interests}

All the authors declare that they have no completing of interest.

\section{Ethical approval and consent to participate}

This study was under the "A Mixed Approach on Determining the factors affecting Brand loyalty with a Moderating role of social trust and Corporate social responsibility: A study on fast food restaurants of Pakistan" approved by the ethics committee of COMSATS Institute of Information Technology, Sahiwal with approval number CIIT/SP13-RMS-004/SWL. The subject provided written consent

\section{Author details}

${ }^{1}$ Department of Marketing, School of Business, University of International, Business and Economics (UIBE), Beijing, China. ${ }^{2}$ School of International Trade and Economics, University of International, Business and Economics (UIBE), No.10, Huixin Dongjie, Chaoyang District, Beijing 100029, China.

Received: 21 April 2020 Accepted: 9 February 2021

Published: 9 March 2021

References

1. Rhou Y, Singal M (2020) A review of the business case for CSR in the hospitality industry. Int J Hosp Manag 84:102330

2. Rana MW, Lodhi RN, Butt GR, Dar WU (2017) How determinants of customer satisfaction are affecting the brand image and behavioral intention in fast food industry of Pakistan? J Tour Hosp 6:316. https:// doi.org/10.4172/2167-0269.1000316

3. Marinkovic V, Senic V, Ivkov D, Dimitrovski D, Bjelic M (2014) The antecedents of satisfaction and revisit intentions for full-service restaurants. Mark Intell Plan 32(3):311-327. https://doi.org/10.1108/ MIP-01-2013-0017

4. Taheri B, Olya H, Ali F (2020) Gannon MJ (2020) Understanding the influence of airport servicescape on traveler dissatisfaction and misbehavior. J Travel Res 59(6):1008-1028. https://doi.org/10.1177/0047287519 877257

5. Ryu K, Han H (2010) Influence of the quality of food, service, and physical environment on customer satisfaction and behavioral intention in quick-casual restaurants: moderating role of perceived price. J Hosp Tour Res 34(3):310-329

6. Namin A (2017) Revisiting customers' perception of service quality in fast food restaurants. J Retail Consum Serv 34:70-81

7. El-Adly MI, ELSamen AA (2018) Guest-based hotel equity: scale development and validation. J Prod Brand Manag 27(6):615-633. https://doi. org/10.1108/JPBM-09-2017-1570

8. Rahi S (2017) Research design and methods: a systematic review of research paradigms, sampling issues and instruments development. Int J Econ Manag Sci 6:403. https://doi.org/10.4172/2162-6359.1000403

9. Santouridis I, Trivellas P (2010) Investigating the impact of service quality and customer satisfaction on customer loyalty in mobile telephony 
in Greece. TQM J 22(3):330-343. https://doi.org/10.1108/1754273101 1035550

10. Asad M, Abid U (2018) CSR practices and customer's loyalty in restaurant industry: moderating role of gender. NUML Int J Bus Manag 13(2):144-155

11. Rew D, Cha W (2020) The effects of resilience and familiarity on the relationship between CSR and consumer attitudes. Soc Respons J. https ://doi.org/10.1108/SRJ-05-2020-0224

12. Line ND, Hanks L, Zhang L (2016) Sustainability communication: the effect of message construals on consumers' attitudes towards green restaurants. Int J Hosp Manag 57:143-151

13. Kim H, Bachman JR (2019) Examining customer perceptions of restaurant restroom cleanliness and their impact on satisfaction and intent to return. J Foodserv Bus Res 22(2):191-208. https://doi. org/10.1080/15378020.2019.1596002

14. Akbari M, Nazarian A, Foroudi P, Amiri NS, Ezatabadipoor E (2020) How corporate social responsibility contributes to strengthening brand loyalty, hotel positioning and intention to revisit? Curr Iss Tour. https://doi.org/10.1080/13683500.2020.1800601

15. Song H, Han H (2019) Effect of image, satisfaction, trust, love, and respect on loyalty formation for name-brand coffee shops. Int J Hosp Manag 79:50-59

16. Uslaner EM (1999) Democracy and social capital. In: Warren M (ed) Democracy and trust. Cambridge University Press, Cambridge, pp $121-150$

17. Delhey J, Newton K (2003) Who trusts? The origins of social trust in seven societies. Eur Soc 5(2):93-137. https://doi.org/10.1080/14616 69032000072256

18. Boix C, Daniel NP (1998) Social capital: explaining its origins and effects on government performance. Br J Polit Sci 28:686-693

19. Putnam RD (1993) Making democracy work: civic traditions in modern Italy. Princeton University Press, Princeton

20. Ndubisi NO (2007) Relationship marketing and customer loyalty. Mark Intel Plan 25(1):98-106

21. Conroy P (2013) Outlook on consumer products. Accessed on 23 June 2018. http://www.deloitte.com/view/en_US/us/Industries/ industryoutlook/02d2ec7080b0b310VgnVCM1000003156f70aRCRD .htm\#.U1 eyiFVdWIm

22. Kim M, Park M, Jeong D (2004) The effects of customer satisfaction and switching barrier on customer loyalty in Korean mobile telecommunication services. Telecommun Policy 2(1):145-159

23. Maloney EA, Ramirez G, Gunderson EA, Levine SC, Beilock SL (2015) Intergenerational effects of parents' math anxiety on children's math achievement and anxiety. Psychol Sci 26(9):1480-1488. https://doi. org/10.1177/0956797615592630

24. Lee TJ, Cho H, Ahn T-H (2012) Senior citizen satisfaction with restaurant service quality. J Hosp Mark Manag 21 (2):215-226

25. Bianchi E, Bruno JM, Sarabia-Sanchez FJ (2019) The impact of perceived CSR on corporate reputation and purchase intention. Eur Manag Bus Econ 28(3):206-221. https://doi.org/10.1 108/EJMBE -12-2017-0068

26. Qin H, Prybutok VR (2009) Service quality, customer satisfaction, and behavioral intentions in fast-food restaurants. Int J Qual Serv Sci 1(1):78-95. https://doi.org/10.1108/17566690910945886

27. Haghighi M, Dorosti A, Rahnama A, Hoseinpour A (2012) Evaluation of factors affecting customer loyalty in restaurant industry. Afr J Bus Manage 6(14):5039-5046

28. Mattila AS (2001) Emotional bonding and restaurant loyalty. Cornell Hotel Restaur Admin Q 42(6):73-79

29. Andaleeb SS, Conway C (2006) Customer satisfaction in the restaurant industry: an examination of the transaction-specific model. J Serv Mark 20(1):3-11

30. Ryu K, Han H (2011) New or repeat customers: How does physical environment influence their restaurant experience? Int J Hosp Manag 30(3):599-611

31. Josiam B, Foster C, Malave R, Baldwin W (2014) Assessing quality of food, service and customer experience at a restaurant: the case of a student run restaurant in the USA. J Serv Res 14(1):49-73

32. Namkung $Y$, Jang $S$ (2008) Are highly satisfied restaurant customers really different? A quality perception perspective. Int I Contemp Hosp Manag 20(2):142-155
33. Schiffman LG, Kanuk LL (2009) Consumer behavior, 10th edn. Prentice-Hall, Upper Saddle River

34. Johns N, Howard A (1998) Customer expectations versus perceptions of service performance in the food service industry. Int J Serv Ind Manag 9(3):248-256

35. Kotler P, Keller KL (2009) Marketing management, 13th edn. Pearson Education Inc, Upper Saddle River

36. Bianchi M, Bressan V (2019) Effectiveness of interprofessional education and new prospects. J Adv Nurs 75:14-16. https://doi. org/10.1111/jan.13772

37. Shin KSS, Amenuvor FE, Basilisco R, Owusu-Antwi K (2019) Brand trust and brand loyalty: a moderation and mediation perspective. Curr J Appl Sci Technol 38(4):1-17. https://doi.org/10.9734/cjast/2019/v38i4 30376

38. Kim WG, Moon YJ (2009) Customers' cognitive, emotional, and actionable response to the servicescape: a test of the moderating effect of the restaurant type. Int J Hosp Manag 28(1):144-150

39. Wong IA, Fong VHI (2010) Examining casino service quality in the Asian Las Vegas: an alternative approach. J Hosp Mark Manag 19(8):842-865. https://doi.org/10.1080/19368623.2010.514553

40. Molinillo S, Ekinci Y, Japutra A (2019) A consumer-based brand performance model for assessing brand success. Int J Mark Res 61(1):93-110. https://doi.org/10.1177/1470785318762990

41. Ha J, Jang SS (2012) The effects of dining atmospherics on behavioral intentions through quality perception. J Serv Mark 26(3):204-215

42. Sharma R, Jain V (2019) CSR, trust, brand loyalty and brand equity: empirical evidences from sportswear industry in the NCR region of India. Metamorphosis 18(1):57-67

43. Isa SM, Ariyanto HH, Kiumarsi S (2020) The effect of place attachment on visitors' revisit intentions: evidence from Batam. Tour Geogr 22(1):5182. https://doi.org/10.1080/14616688.2019.1618902

44. Dutta A, Gogol M, Kim JH, Smolle M, Venkatesh S, Gilmore J, Florens L, Washburn MP, Workman JL (2014) Swi/Snf dynamics on stress-responsive genes is governed by competitive bromodomain interactions. Genes Dev 28(20):2314-2330

45. Bitner MJ (1990) Evaluating service encounters: the effects of physical surroundings and employee responses. J Mark 54(2):69-82

46. ZeithamI VA, Berry LL, Parasuraman A (1993) The nature and determinants of customer expectations of service. J Acad Mark Sci 21:1-12

47. Guillet BD, Kozak M, Kucukusta D (2019) It's in the air: aroma marketing and affective response in the hotel world. Int J Hosp Tour Admin 20(1):1-14. https://doi.org/10.1080/15256480.2017.1359727

48. Auty S (1992) Consumer choice and segmentation in the restaurant industry. Serv Ind J 12(3):324-339

49. Liu C-HS, Su C-S, Gan B, Chou S-F (2014) Effective restaurant rating scale development and a mystery shopper evaluation approach. Int J Hosp Manag 43:53-64

50. Chang K (2000) The impact of perceived physical environments on customer's satisfaction and return intentions. J Prof Serv Mark 21(2):75-85

51. Annamdevula S, Bellamkonda RS (2016) The effects of service quality on student loyalty: the mediating role of student satisfaction. J Model Manag 11(2):446-462. https://doi.org/10.1108/JM2-04-2014-0031

52. Klassen JK, Trybus E, Kumar A (2005) Planning food services for a campus setting. Hosp Manag (in Press)

53. Kivela J, Inbakaran R, Reece J (2000) Consumer research in the restaurant environment. Int J Contemp Hosp Manag 12(1):13-30

54. Lewis RC, Shoemaker S (1997) Price-sensitivity measurement: a tool for the hospitality industry. Cornell Hotel Restaur Admin Q 38:44-47

55. Dhisasmito PP, Kumar S (2020) Understanding customer loyalty in the coffee shop industry (a survey in Jakarta, Indonesia). Br Food J 122(7):2253-2271. https://doi.org/10.1 108/BFJ-10-2019-0763

56. Prendergast G, Man HW (2002) The influence of store image on store loyalty in Hong Kong's quick service restaurant industry. J Foodserv Bus Res 5(1):45-59

57. Hassan H, Sade AB, Rahman MS (2013) Malaysian hypermarket retailing development and expansion. Int J Retail Distrib Manag 41(8):584-595

58. ZeithamI VA (1988) Consumer perceptions of price, quality and value: a means and model and synthesis of evidence. J Mark 52:2-22

59. Pride WM, Ferrell OC (2003) Marketing: concepts and strategies. Houghton Mifflin Company, Boston 
60. Sadia J, Tasneem F, Khan M (2011) An empirical analysis of customer loyalty in Pakistan's telecommunication industry. Database Mark Customer Strategy Manag 18(1):5-15

61. Wu HC, Cheng CC (2019) An empirical analysis of green experiential loyalty: a case study. J Int Food Agribus Mark 31(1):69-105. https://doi org/10.1080/08974438.2018.1482484

62. Oliver RL, Swan JE (1989) Consumer perceptions of interpersonal equity and satisfaction in transactions: a field survey approach. J Mark 53:21. https://doi.org/10.2307/1251411

63. Bolton RN, Lemon KN (1999) A dynamic model of customers' usage of services: usage as an antecedent and consequence of satisfaction. J Mark Res 36(2):171-186

64. Ali Shafiq M, Mostafiz I, Taniguchi M (2019) Using SERVQUAL to determine generation $Y^{\prime}$ 's satisfaction towards hoteling industry in Malaysia. J Tour Futures 5(1):62-74. https://doi.org/10.1108/JTF-01-2018-0004

65. Alexakis $G$, Jiang $L$ (2019) Industry competencies and the optimal hospitality management curriculum: an empirical study. J Hosp Tour Educ 31(4):210-220. https://doi.org/10.1080/10963758.2019.1575748

66. Van der V, Van Dongen S, Nougier S, Hilhorst R (2002) E-business initiatives in food supply chains: definition and typology of electronic business models. Int J Log Res Appl 5(2):119-138

67. Nield K, Kozak M, Geoffrey LeGrys G (2000) The role of food service in tourist satisfaction. Int J Hosp Manag 19(4):375-384

68. Barbara E Kahn (1995) Consumer variety-seeking among goods and services: an integrative review. J Retail Consumer Serv 2(3):139-148

69. Ratner RK, Kahn BE, Kahneman D (1999) Choosing less—-preferred experiences for the sake of variety. J Consumer Res 26:1-15

70. Zandstra EH, De Graaf C, Van Trijp HCM (2000) Effects of variety and repeated in-home consumption on product acceptance. Appetite 35(2):113-119

71. Bjorvatn T, Wald A (2020) The impact of time pressure on knowledge transfer effectiveness in teams: trust as a critical but fragile mediator. J Knowl Manag. https://doi.org/10.1108/JKM-05-2020-0379

72. Alhabeeb MJ (2007) On consumer trust and product loyalty. Int J Consumer Stud 31(6):609-612

73. Worthington S, Russell-Bennett R, Hartel CEJ (2009) A tridimensional approach for auditing brand loyalty. J Brand Manag 17(4):243-253

74. Cunningham RM (1961) Customer loyalty to store and brand. Harvard Bus Rev 39(6):127-137

75. Farley JU (1964) Why does brand loyalty vary over products? J Mark Res 1(4):9-14

76. Oliver RL (1999) Whence customer loyalty? J Mark 63:33-44

77. Sheth J (1974) 'Keasureirent of advertising effectiveness: some theoretical considerations. J Advert 3:6-11

78. Nilsson O, Olsen J (1995) Measuring consumer retail store loyalty. Eur Adv Consum Res 2(1):289-297

79. Flavián C, Guinalíu M (2006) Consumer trust, perceived security, and privacy policy: three basic elements of loyalty to a website. Ind Manag Data Syst 106(5/6):601-620

80. Tsoukatos E, Rand G (2006) Path analysis of perceived service quality, satisfaction and loyalty in Greek insurance. ManagServ Qual 5(1):501-519

81. Mohammed A, Rashid B (2018) A conceptual model of corporate social responsibility dimensions, brand image, and customer satisfaction in Malaysian hotel industry. Kasetsart J Soc Sci 39(2):358-364

82. Giebelhausen MD, Chan E, Sirianni NJ (2016) Fitting restaurant service style to brand image for greater customer satisfaction. Cornell Hosp Rep 16(9):3-10

83. Khadka K, Maharjan S (2017) Customer satisfaction and customer loyalty. Master's Thesis, Centria University of Applied Sciences, Business Management, Lahti, Finland

84. Bennett R, Rundle-Thiele S (2004) Customer satisfaction should not be the only goal. J Serv Mark 18:514-523

85. Baig E, Khan S (2010) Emotional satisfaction and brand loyalty in hospitality industry. Int Bull Bus Admin Euro J 9(7):34

86. Han H, Back K (2006) Investing the effects of consumption emotions on customer satisfaction and repeat visit intentions in the lodging industry. J Hosp Leisure Mark 15(3):5-30

87. Rajput A, Gahfoor RZ (2020) Satisfaction and revisit intentions at fast food restaurants. Future Bus J 6(1):1-12
88. Han H, Ryu K (2006) Moderating role of personal characteristics in forming restaurant customers' behavioral intentions - an upscale restaurant setting. J Hosp Leisure Mark 15(4):25-54

89. Kandampully J, Suhartanto D (2000) Customer loyalty in the hotel industry: the role of customer satisfaction and image. Int J Contemp Hosp Manag 12(6):346-351

90. Abdullah RB (2012) The relationship between store band and customer loyalty in retailing in Malaysia. Asian Soc Sci 8(2):117-185

91. Simmel G (1950) The sociology of Georg Simmel (Translated and edited by KW Glencoe). Illinois: The Free Press

92. Burleigh TL, Griffiths MD, Sumich A et al (2019) A systematic review of the co-occurrence of gaming disorder and other potentially addictive behaviors. Curr Addict Rep 6:383-401. https://doi.org/10.1007/s4042 9-019-00279-7

93. Chalabi M (1996) Sociologists order. Ney Publishing, Tehran

94. Thomsen JPF, Rafiqi A (2020) Ideological biases weaken the impact of social trust on ethnic outgroup threat. Polit Stud 68(2):523-540. https:// doi.org/10.1177/0032321719862751

95. Jacob C, Roth G, Flanders J et al (2017) Experiences with counselor training in central Europe: voices from student trainees. Int J Adv Counsel 39:43-55. https://doi.org/10.1007/s10447-016-9281-8

96. Uslaner EM (2000) Producing and consuming trust. Polit Sci Q 115(4):569-590

97. Campaert K, Nocentini A, Menesini E (2018) The role of poor parenting and parental approval for children's moral disengagement. J Child Fam Stud 27:2656-2667. https://doi.org/10.1007/s10826-018-1097-1

98. Giddens A (1990) The consequences of modernity. Stanford University Press, Stanford

99. Coleman JS (1988) Social capital in the creation of human capital. Am J Sociol 94:95-120

100. Maloney W, Smith G, Stoker G (2001) Social capital and the city. In: Beyond tocqueville: civil society and the social capital debate in comparative perspective. Hanover, NH, Tufts University/University of New England Press, pp 83-96

101. Brewer MB (2008) Depersonalized trust and ingroup cooperation. In: Krueger II (ed) Rationality and social responsibility. Psychology Press, New York, pp 215-232

102. Putnam R (2000) Bowling alone: the collapse and revival of american community. Simon and Schuster, New York

103. Boone C, De Brabander B, van Witteloostuijn A (1999) The impact of personality on behavior in five prisoner's dilemma games. J Econ Psychol 20:343-377

104. Ledyard JO (1995) Public goods: a survey of experimental research. In: Kagel JH, Roth AE (eds) The hand book of experimental economics. Princeton University Press, Princeton

105. Liu Y, Jang SCS (2009) The effects of dining atmospherics: an extended Mehrabian-Russell model. Int J Hosp Manag 28(4):494-503

106. Woods D (1991) Teachers' interpretations of second language teaching curricula. RELC J 22(2):1-18. https://doi.org/10.1177/003368829102200 201

107. Carroll AB (1999) Corporate social responsibility: evolution of a definitional construct. Bus Soc 38(3):268-295. https://doi.org/10.1177/00076 5039903800303

108. Rashidin MS, Javed S, Liu B, Jian W (2020) Ramifications of households' nonfarm income on agricultural productivity: evidence from a rural area of Pakistan. SAGE Open. https://doi.org/10.1177/215824402090209 1

109. Maxham JG, Netemeyer RG (2002) A longitudinal study of complaining customers' evaluations of multiple service failures and recovery efforts. J Mark 66(4):57-71. https://doi.org/10.1509/jmkg.66.4.57.18512

110. Rastini NM, Nurcaya N (2019) Customers trust mediation: effect of CSR and service quality towards e-WOM. Int Res J Manag IT Soc Sci 6(4):169-173. https://doi.org/10.21744/irjmis.v6n4.670

111. Szöcs I (2013) Coporate philanthropy and corporate reputation. Inf Manag Bus Rev 5(3):194-202

112. Fombrun CJ, Gardberg NA, Barnett ML (2000) Opportunity plat-forms and safety nets: corporate citizenship and reputational risk'. Bus Soc Rev 105:85-106

113. Fan $Y$ (2005) What corporate social responsibility activities are valued by the market. J Bus Ethics 26(6):189-206 
114. Onlaori W, Rotchanakitumnuai S (2010) Enhancing customer loyalty towards corporate social responsibility of Thaimobile service providers. World Acad Sci Eng Technol 66:1575-1578. Retrieved from http://waset .org/journals/waset/v66/v66-242.pdf

115. Wirtz J, Mattila AS, Oo LM (2007) How effective are loyalty reward programs in driving share of wallet? J Serv Res 9(4):327-334. https://doi. org/10.1177/1094670506295853

116. Allen MJ, Yen WM (2001) Introduction to measurement theory. Waveland Press ISBN 147860770X, 9781478607700

117. Liang $X$, Zhang S (2009) Investigation of customer satisfaction in student food service: an example of student cafeteria in NHH. Int J Qual Serv Sci 1:113-124

118. Brown TJ, Dacin PA (1997) The company and the product: corporate associations and consumer product responses. J Mark 61:68-84

119. Sahagun MA, Vasquez-Parraga SZ (2014) Can fast-food consumers be loyal customers, if so how? Theory, method and findings. J Retail Consumer Serv 21(2):168-174

120. Newton K (2001) Social trust and political disaffection: social capital and democracy. EURESCO Conference on Social capital, Exeter

121. Glaeser EL, Laibson DI, Scheinkman JA, Soutter CL (2001) Measuring trust. Q J Econ 811-846

122. Justwan F, Bakker R, Berejikian JD (2018) Measuring social trust and trusting the measure. Soc Sci J 55(2):149-159. https://doi.org/10.1016/j. soscij.2017.10.001

123. Rosenberg M (1957) Misanthropy and attitudes towards international affairs. J Conflict Resolut 1(340):5

124. Tabachnick BG, Fidell LS (2007) Using multivarite statistics, 5th edn. Pearson Education Inc, Allyn and Bacon

125. Simamora B (2005) Analysis multivariate pemasaran. Gramedia Pustaka Utama, Jakarta

126. Ruyter KO, Bloemer J (1999) Customer loyalty in extended service settings. Int J Serv Ind Manag 10(3):320-336. https://doi. org/10.1108/09564239910276917

127. Anderson JC, Gerbing DW (1988) Structural equation modeling in practice: a review and recommended two-step approach. Psychol Bull 103(3):411

128. Hair JF, Hult GTM, Ringle CM, Sarstedt M, Thiele KO (2017) Mirror, mirror on the wall: a comparative evaluation of composite-based structural equation modeling methods. J Acad Mark Sci 45(5):616-632. https:// doi.org/10.1007/s11747-017-0517-x

129. Seckler M, Klaus $O$ (2015) Trust and distrust on the web: user experiences and website characteristics. Comput Hum Behav 45:39-50

130. Salamun Rashidin M, Javed S, Liu B (2020) Empirical study on spirituality, employee's engagement and job satisfaction: evidence from China. Int J Public Admin 43(12):1042-1054. https://doi.org/10.1080/01900 692.2019.1665066

131. Javed S, Rashidin S, Jian W (2018) What really matters? A triumph of brand extension: evidence from Engro Corporation. J Polit Econ Manag 1(2):1-16

132. Elbeltagi I, Agag G (2016) E-retailing ethics and its impact on customer satisfaction and repurchase intention. Internet Res 26(1):288-310. https ://doi.org/10.1108/IntR-10-2014-0244

133. Podsakoff P, MacKenzie S, Lee Y, Podsakoff N (2003) Common method biases in behavioral research: a critical review of the literature and recommended remedies. J Appl Psychol 88(5):879-903. https://doi. org/10.1037/0021-901088.5.879

134. Hu L, Bentler PM (1999) Cutoff criteria for fit indexes in covariance structure analysis: conventional criteria versus new alternatives. Struct Equ Model Multidiscip J 6(1):1-55. https://doi.org/10.1080/1070551990 9540118

135. Hair JF, Black WC, Babin BJ, Anderson RE (2010) Multivariate data analysis: a global perspective, 7th edn. Pearson Education, Upper Saddle River

136. Fornell C, Larcker DF (1981) Evaluating structural equation models with unobservable variables and measurement error. J Mark Res 18(1):39. https://doi.org/10.2307/3151312

137. Kline RB (2005) PsycNET record display_PsycNET. http://psycnet.apa. org/record/2005-03476-000

138. Schreiber JB (2008) Core reporting practices in structural equation modeling. Res Soc Admin Pharmacy 4(2):83-97

139. Falk RF, Miller NB (1992) A primer for soft modeling. The University of Akron Press

140. Cohen J (1988) In: Hillsdale NJ (ed) Statistical power analysis for the behavioral sciences, 2nd edn. L. Erlbaum Associates. Retrieved from http://www.worldcat.org/title/statistical-power-analysis-for-the-behav ioral-sciences/oclc/17877467

141. Aiken L, West S, Reno R (1991) Multiple regression: testing and interpreting interactions. Sage Publications, Thousand Oaks

142. Hwang E, Baloglu S, Tanford S (2019) Building loyalty through reward programs: the influence of perceptions of fairness and brand attachment. Int J Hosp Manag 76:19-28

143. Naderi I, Paswan AK, Guzman F (2018) Beyond the shadow of a doubt: the effect of consumer knowledge on restaurant evaluation. J Retail Consumer Serv 45:221-229. https://doi.org/10.1016/j.jretconser .2018.09.004

144. Yinghua $L$, Jang SCS (2009) Perceptions of Chinese restaurants in the U.S.: What affects customer satisfaction and behavioral intentions? Int J Hosp Manag 28(3):338-348

145. Shahzadi M, Malik SA, Ahmad M, Shabbir A (2018) Perceptions of fine dining restaurants in Pakistan: What influences customer satisfaction and behavioral intentions? Int J Qual Reliab Manag 35(3):635-655. https //doi.org/10.1108/IJQRM-07-2016-0113

146. WVS 2010-2012 Wave, revised master (2012) Assess 06 Sep 2020. http:// www.worldvaluessurvey.org/WVSDocumentationWV6.jsp

147. Dutta K, Parsa HG, Parsa RA, Bujisic M (2014) Change in consumer patronageand willingness to pay at different levels of service attributes in restaurants: astudy in India. J Qual Assur Hosp Tour 15(2):149-174. https://doi.org/10.1080/1528008x.2014.889533

148. Barua Z, Aimin W, Hongyi X (2018) A perceived reliability-based customer satisfaction model in self-service technology. Serv Ind J 38(7-8):446-466. https://doi.org/10.1080/02642069.2017.1400533

\section{Publisher's Note}

Springer Nature remains neutral with regard to jurisdictional claims in published maps and institutional affiliations.

\section{Submit your manuscript to a SpringerOpen ${ }^{\circ}$ journal and benefit from:}

- Convenient online submission

- Rigorous peer review

- Open access: articles freely available online

- High visibility within the field

Retaining the copyright to your article

Submit your next manuscript at springeropen.com 